\title{
Chemical Characterization of CHIA (Salvia hispanica L.) for Use in Food Products
}

\author{
Michele Silveira Coelho, Myriam de las Mercedes Salas-Mellado* \\ Laboratory of Food Technology, School of Chemistry and Food, Federal University of Rio Grande Rio Grande, Rio Grande do Sul, Brazil \\ *Corresponding author: mysame@yahoo.com
}

Received April 21, 2014; Revised May 24, 2014; Accepted May 28, 2014

\begin{abstract}
Chia is a seed native to the region that extends from the North of Mexico to Guatemala, and it has been target of study for food enrichment. Many of its newly developed functional foods contain bioactive compounds including dietary fiber, antioxidants and other substances. The objective of this study was to evaluate chia seed (Salvia hispanica $L$ ) from her chemical components and prove their claim for functional properties. Chia seeds contain high levels of lipids (34.4\%) and are rich in Omega-3, Omega-6 and Omega-9, which constituted 62, 17.4 and $10.5 \%$ of the total lipids, respectively. Chia seed also contain fibers $(23.7 \%)$ and proteins (19.6\%). Their extracted phenolic compounds (32.35 $\mu \mathrm{g}_{\mathrm{GAE}} \cdot \mathrm{mL}_{\text {extract }}{ }^{-1}$ ) showed antioxidant activity. From the results obtained in the analysis, one should explore the use of this seed in food products, aiming at adding nutritional value and producing foods which contribute to the well-being and health of humans.
\end{abstract}

Keywords: antioxidants, functional food, Omega-3, Salvia hispanica L.

Cite This Article: Michele Silveira Coelho, and Myriam de las Mercedes Salas-Mellado, “Chemical Characterization of CHIA (Salvia hispanica L.) for Use in Food Products." Journal of Food and Nutrition Research, vol. 2, no. 5 (2014): 263-269. doi: 10.12691/jfnr-2-5-9.

\section{Introduction}

The search for novel foods is a relevant practice worldwide. Salvia hispanica L., also known as chia, is an herbaceous plant cultivated semi-annually, and it belongs to the family Labiatae, division Spermatophyta and kingdom Plantae [1]. Chia is native to the region that stretches from North Mexico to Guatemala. Its seeds were widely used by Aztec tribes for food, medicine and paints [2]. Chia seed contains a significant amount of lipids (approximately $40 \%$ of the total weight), with almost $60 \%$ of the lipids comprising Omega-3 fatty acids. Dietary fiber constitutes more than $30 \%$ of the total weight of the seed, and approximately $19 \%$ of the seed contains proteins of high biological value [3]. Unsaturated Omega-3 fatty acids are nutritionally important for good health and are beneficial for individuals suffering from heart disease, diabetes and immune response disorders [4].

Functional foods have received heavy attention in recent years as components of healthy lifestyle changes. The term "functional" is used to refer to a food that is regularly consumed to provide physiological benefits or to reduce the risk of chronic disease in addition to its basic nutritional functions. Many new foods contain bioactive functional compounds including fiber, prebiotics, probiotics, oligosaccharides, phytochemicals, antioxidants, and other substances that confer functional properties or beneficial effects on human health [5]. Functional foods offer health benefits in addition to the nutritional value inherent in their chemical compositions, and they may have potential roles in reducing the risk of chronic degenerative diseases [6]. Important functional foods that need to be consumed on a daily basis are fruits, vegetables, legumes and grains; these materials generally provide the body a high intake of vitamins, minerals, phytochemicals (antioxidants and anticarcinogenic molecules) and fibers, which are essential for the proper functioning of the organism and for the maintenance of health [5].

Natural antioxidants protect the human body against free radicals, inhibit many chronic diseases, and prevent lipid oxidation in food. Phenolic compounds are important components of many edible plants, including soybean, canola, flaxseed and olive, which are used as food or food ingredient sources [7]. Synthetic antioxidants are widely used for its performance; however, they present different toxicological problems [8]. The legislation on food safety has gradually become more rigorous, requiring the use of toxicity tests for synthetic antioxidants. Additionally, consumers tend to use natural products as antioxidants, as these appear safe and do not require pre-testing [9]. Chia seeds are a promising source of antioxidants due to the presence of polyphenols, chlorogenic and caffeic acids, myricetin, quercetin and kaempferol $[3,10]$, which protect consumers against adverse conditions such as cardiovascular diseases and certain cancers [11,12]. Thus, the objective of this work was to evaluate chia seed (Salvia hispanica L.) for its chemical components and to extract its phenolic compounds for the evaluation of their antioxidant activity.

\section{Materials and Methods}


The seeds of chia (Salvia hispanica L.), were provided by Chá e Cia - Medicinal Herbs for Tea, located in Jacareí, São Paulo. Twigs were removed from seeds with tweezers. Chia seeds were ground with a double knife crusher (Arno, model PL pic-liq), sieved through mesh with a granulometry of 16 mesh, packed in plastic bugs and stored at $4^{\circ} \mathrm{C}$ until the performance of the tests.

Proximal composition, caloric value and water holding capacity (WHC). The moisture content (method $\mathrm{n}^{\circ}$ 935.29), ashes (method $n^{\circ}$ 923.03), lipids (method $n^{\circ}$ 920.85), proteins (micro-Kjeldahl method, $n^{\circ} 920.87$ ) and dietary fiber (total digestion of the material in the $1.25 \%$ $\mathrm{w} / \mathrm{v} \mathrm{H}_{2} \mathrm{SO}_{4}$ for $30 \mathrm{~min}$, followed by $1.25 \% \mathrm{w} / \mathrm{v} \mathrm{NaOH}$ for $30 \mathrm{~min}$ ) of chia seeds were determined according to the Association of Official Analytical Chemists [13] criteria. The carbohydrate content was obtained by difference between 100 and the sum of ashes, lipids, proteins and dietary fiber.

The caloric value of the samples was calculated from the Atwater coefficients [14], taking the caloric coefficients corresponding to proteins, carbohydrates and lipids, as shown in Equation (1).

$$
\begin{aligned}
& \text { Caloric value }\left(\text { kcal.100 } \mathrm{g}^{-1}\right) \\
& =(\mathrm{g} \text { of protein } * 4)+(\mathrm{g} \text { of lipids } * 9) \\
& +(\mathrm{g} \text { of carbohydrates } * 4)
\end{aligned}
$$

The water holding capacity (WHC) was determined as described in Regenstein et al [15].

Fatty acids profile. Oil was extracted from chia seed by acid hydrolysis [16]. The transformation into methyl esters and fatty acid composition were determined according to the AOAC [16] criteria using a gas chromatograph (Thermo, model Focus GC, detector FID).

The chromatographic conditions used were as follows: initial column temperature, $100^{\circ} \mathrm{C}$ for $4 \mathrm{~min}$, final column temperature, $240^{\circ} \mathrm{C}$ with speed of $3^{\circ} \mathrm{C} \cdot \mathrm{min}^{-1}$, injector temperature, $225^{\circ} \mathrm{C}$, and detector temperature, $285^{\circ} \mathrm{C}$. The drag gas used was helium, and the SP2560 capillary column was $100 \mathrm{~m}$ x $0.25 \mathrm{~mm}$.

Extraction and quantification of phenolic compounds. The extraction and quantification of phenolic compounds was performed as described by Badiale-Furlong et al. [17]. A total of $5 \mathrm{~g}$ of the sample was incubated with $40 \mathrm{~mL}$ of methanol under horizontal agitation $(5 \times \mathrm{g}$ ) for $2 \mathrm{~h}$ hat $25^{\circ} \mathrm{C}$, allowed to rest for $15 \mathrm{~min}$, and shaken again (1h) after adding $10 \mathrm{~mL}$ of methanol. The extract was filtered and washed three times with hexane. The extract was clarified with $0.1 \mathrm{M}$ barium hydroxide and $5 \%$ zinc sulfate for $20 \mathrm{~min}$, filtered and carried to a final volume of $50 \mathrm{~mL}$ with methanol.

Quantification of phenolic compounds was carried out spectrophotometrically using Folin-Ciocalteu reagent. Aliquots of $0.5 \mathrm{~mL}$ of the phenolic extracts were added to test tubes along with $0.5 \mathrm{~mL}$ of distilled water and $4.5 \mathrm{~mL}$ of alkaline solution (4\% $\mathrm{Na}_{2} \mathrm{CO}_{3}, 2 \% \mathrm{CuSO}_{4}$ and $4 \%$ potassium sodium tartrate in a 100:1:1 ratio). The tubes were incubated for $15 \mathrm{~min}$ in a $40{ }^{\circ} \mathrm{C}$ water bath. Afterwards, $0.5 \mathrm{~mL}$ of the Folin-Ciocalteu assay reagent (diluted 1:2 in distilled water) was added, and the tubes were incubated at room temperature for 10 minutes. The absorbance at $750 \mathrm{~nm}$ was measured in a spectrophotometer (IONLAB, model IL-592). For quantification, a calibration curve was prepared using gallic acid (GAE) in concentrations of 0 to $20 \mu \mathrm{g} \cdot \mathrm{mL}^{-1}$.

Phenolic compounds profile. Chromatographic patterns for the determination of phenolic compounds (cinnamic acid, chlorogenic acid, caffeic acid and quercetin) were obtained from Sigma Chemicals Co. (St. Louis, MO) with 99\% purity. We used a Milli-Q system (Millipore, Bedford, MA, USA) with a $0.22 \mu \mathrm{m}$ pore filter to purify water for the mobile phase.

For the separation, identification and chromatographic quantification of phenolic compounds, chia extract was used to be analyzed in a liquid chromatograph (HPLC) via a binary pump and UV-VIS detector with a 50- $\mu$ l loop injector and a column C18, 250 x $4.6 \mathrm{~mm} 100 \AA$, $5 \mu \mathrm{m}$. For the patterns of chlorogenic, caffeic and cinnamic acids, an ultra efficiency liquid chromatograph (UPLC) set-up was composed of a binary bomb detector, PDA, gun with a 3- $\mu \mathrm{L}$ loop and C18 column - 2, 1x50 mm, $1.7 \mu \mathrm{m}$ (Acquiy UPLC BEH - Waters).

The mobile phase elution was performed with a gradient of acetic acid $(0.5 \%, \mathrm{v} / \mathrm{v})$ and water, acetic acid and butanol (350:1:10 v/v/v), an aqueous solution of $0.1 \%$ phosphoric acid and $0.1 \%$ methanol and methanol, which varied as described in Table 1 and Table 2, with 0.45 and $1.0 \mathrm{~mL} \mathrm{~min}{ }^{-1}$ flow, resulting in a total time of 10 and 50 min race. The injected volume was 3 and $5 \mu \mathrm{L}$.

Table 1. Elution gradient program of solvents for the separation of phenolic compounds (cinnamic, caffeic and chlorogenic acids) in chia seeds

\begin{tabular}{ccc}
\hline Time Interval (min) & Acetic acid (\%) & $\begin{array}{c}\text { Water/Acetic acid/Butanol } \\
(350: 1: 10)(\%)\end{array}$ \\
\hline $0.0-0.4$ & 10 & 90 \\
$2.4-3.4$ & 5 & 95 \\
$3.5-4.5$ & 1 & 99 \\
$4.8-4.9$ & 5 & 95 \\
$8.0-10.0$ & 10 & 90 \\
\hline
\end{tabular}

Table 2. Elution gradient program of solvents for the separation of phenolic compounds (quercetin) in chia seeds

\begin{tabular}{ccc}
\hline Time Interval (min) & $\begin{array}{c}\text { Phosphoric } \\
\text { acid/Methanol (\%) }\end{array}$ & Methanol (\%) \\
\hline 0.0 & 78 & 22 \\
33.0 & 0 & 100 \\
$40.0-50.0$ & 78 & 22 \\
\hline
\end{tabular}

To identify the compounds in the mixture (cinnamic, caffeic and chlorogenic acids), the retention times and peak spectra of the samples were compared with the patterns. Each pattern was analyzed individually to determine its retention times and prescriptive UV curves, the patterns were later combined for quantification.

Analytical curves and the linear UV-visible detector responses for the phenolic compounds were evaluated against an analytic curve constructed by injecting five standard solutions in concentrations of $0.8-20 \mathrm{mg} . \mathrm{Kg}-1$ chlorogenic acid, cinnamic acid, caffeic acid and quercetin. The limits of detection for each compound were 1.5-3.0 mg. $\mathrm{kg}^{-1}$ for chlorogenic acid and caffeic acid, 5.0-15.0 mg. $\mathrm{kg}^{-1}$ for cinnamic acid and $0.04-0.1 \mathrm{mg} \cdot \mathrm{kg}^{-1}$ for quercetin. The content of phenolic glycoside dust was obtained as the difference because hydrolysis is required to quantify and verify the bioavailability of these compounds [18]. 


\subsection{Evaluation of Antioxidant Activity of Phenolic Compounds}

Free radical sequestration capacity of the 2.2-diphenyl1-picrylhydrazyl (DPPH). The consumption of free radicals from DPPH by the phenolic extracts and control reaction was monitored as described by Herrero et al. [19] with modifications to determine the decrease in absorbance units (AU) in the solutions containing phenolic extracts. The measurements were performed on a spectrophotometer (IONLAB, model IL-592) at a wavelength of $515 \mathrm{~nm}$, using a gallic acid equivalent control. A total of $1 \mathrm{~mL}$ of the phenol extract was added to tubes containing $3.0 \mathrm{~mL}$ of a methanol solution of DPPH $\left(5.2 \times 10^{-5}\right.$ mol. $\left.\mathrm{L}^{-1}\right)$. For blank reactions, $1 \mathrm{~mL}$ of methanol replaced the phenolic extracts. Reaction tubes were incubated at room temperature in the dark, and the color change from yellow to violet was measured after $0,30,60$, 90, 120, 150, 180 and 210 min. The DPPH solution was prepared daily, stored in amber bottles covered with aluminum foil, and kept in the dark at $4^{\circ} \mathrm{C}$ until its use.

The ability to sequester the free radical was expressed as a percent inhibition of oxidation of the radical and calculated according to Equation (2).

$$
\% \text { Inhibition }=\frac{A U_{\text {blank }}-A U_{\text {sample }}}{A U_{\text {blank }}} \times 100 \%
$$

Where $\mathrm{AU}_{\text {blank }}$ correspond to the absorbance units of blank and $\mathrm{AU}_{\text {sample }}$ correspond to the sample absorbance units.

Inhibition of enzymatically catalyzed oxidation. Inhibition of enzymatically catalyzed oxidation was performed according to Oliveira et al. [20]. Peroxidase was extracted from potato (Solanum tuberosum). The enzymatic extract was obtained from $20 \mathrm{~g}$ of homogenized potato pulp that was stirred in blender for 3 min with 100 $\mathrm{mL}$ of phosphate buffer $\mathrm{pH} 6.5(20 \mathrm{mM})$. The homogenate was centrifuged at $3220 \mathrm{xg}$ at $4^{\circ} \mathrm{C}$ for $10 \mathrm{~min}$ and filtered. The crude extract (supernatant) was maintained at approximately $4^{\circ} \mathrm{C}$.

Enzymatic browning reactions using the phenolic compounds of chia and the control (GAE) were performed at $30{ }^{\circ} \mathrm{C}$ at $\mathrm{pH} 6.5$ using $1 \%$ guaiacol as the substrate in the presence of $0.08 \% \mathrm{H}_{2} \mathrm{O}_{2}$. The phenolic extracts/control (1 mL) were added as reaction inhibitors, and blank phenolic extract volume was replaced by distilled water. To these solutions, the remaining reaction components were added, including $1.5 \mathrm{~mL}$ of phosphate buffer $\mathrm{pH}$ 6.5, $1 \mathrm{~mL}$ of distilled water, $1 \mathrm{~mL}$ of hydrogen peroxide $0.08 \%$, $0.5 \mathrm{~mL}$ of $1 \%$ guaiacol and $1 \mathrm{~mL}$ of peroxidase enzymatic extract. The tubes were shaken, and the absorbance was measured at $470 \mathrm{~nm}$ in an IONLAB model IL-592 spectrophotometer after 10, 15, 20, 30 and $40 \mathrm{~min}$. The antioxidant activity was expressed as the percent inhibition of the color-change reaction relative to the control, as shown in Equation (2).

Treatment of the data. The results were compared by analysis of variance (ANOVA), and the average results were compared by the Tukey test with 95\% statistical significance $(\alpha), p<0.05$, using Statistica 5.0 software. All analyses, except the fatty acid and phenolic compound profiles, were carried out in triplicate.

\section{Results and Discussion}

Chemical composition of chia seeds (Salvia hispanica L.). The proximal composition analysis (Table 3) showed a higher content of dietary fiber, $22.1 \mathrm{~g} .100 \mathrm{~g}^{-1}$, than previously reported by Tosco [21]. The lipid content, 33 g. $100 \mathrm{~g}^{-1}$, was similar to the amount reported by Ixtaina et al. [3]. The levels of protein and ash were similar to the values found by Ayerza and Coates [11] and were 23 g. $100 \mathrm{~g}^{-1}$ and $4.6 \mathrm{~g} .100 \mathrm{~g}^{-1}$, respectively. The moisture, ash and lipid contents were 6.3, 4.3 and 34.9 g.100 g-1, respectively, which were similar to results published by Segura-Campos et al. [22], but the protein and fiber content 24.0 and 35.8 g.100 g-1, respectively, were different.

With all these features, chia seeds can be used as emulsifiers and stabilizers due to their high fiber content, and as an ingredient for products gluten-free, and with low carbohydrate content. In addition, there is the possibility of extracting oil for production of capsules of $\omega-3$, and protein concentrates obtained due to their protein content. So, chia seeds can be used for enrichment of products, such as cookies, cereal bars and bakery.

Table 3. Proximal composition and calorific value of chia seed

\begin{tabular}{|c|c|c|}
\hline Component & $\%$ w.b. $^{a}$ & $\%$ d.b. ${ }^{a}$ \\
\hline Humidity (g.100 g ${ }^{-1}$ ) & $6,2 \pm 0,517$ & - \\
\hline Ashes (g.100 g $\left.{ }^{-1}\right)$ & $4,3 \pm 0,035$ & $4,6 \pm 0,035$ \\
\hline Proteins (g.100 g ${ }^{-1}$ ) & $18,3 \pm 1,613$ & $19,6 \pm 1,720$ \\
\hline Dietary fiber (g.100 g ${ }^{-1}$ ) & $22,2 \pm 0,323$ & $23,7 \pm 0,424$ \\
\hline Lipids (g.100 g ${ }^{-1}$ ) & $32,4 \pm 0,214$ & $34,4 \pm 0,353$ \\
\hline Other carbohydrates (g.100 g g $^{-1}$ ) & $16,5 \pm 1,628$ & $17,7 \pm 1,465$ \\
\hline Caloric value (Kcal.100 g ${ }^{-1}$ ) & $431,2 \pm 3,123$ & $459,9 \pm 2,394$ \\
\hline
\end{tabular}

${ }^{a}$ w.b.: wet basis, d.b.: dry basis.

According to Lima et al. [23], flaxseed has a caloric value of $495 \mathrm{Kcal} 100 \mathrm{~g}^{-1}$, similar to chia seeds (Table 3). Like chia seeds, flaxseeds are a renewable source rich in $\omega$-3 and other functional components [24], and their use in formulations increases the $\omega-3$ fatty acid content of popular foods. The high caloric value presented by chia seeds is associated with its high levels of lipids. From a nutritional standpoint, lipids have a high energy value (9 Kcal.g ${ }^{-1}$ ) and are important precursors of fat-soluble vitamins (A, D, E and K) and essential fatty acids (linoleic, linolenic and arachidonic acids) [25]. Similar to the value found in this study, Jin et al. [26] found a caloric value for chia seed of $562 \mathrm{Kcal} 100 \mathrm{~g}^{-1}$

Chia seeds contain 5-6\% mucilage, which can be used as dietary fiber [10,11]. Muñoz et al. [27] studied the hydration of chia mucilage, finding that a $100 \mathrm{mg}$ sample of mucilage absorbs $2.7 \mathrm{~g}$ of water, which is 27 times its own weight. Compared with other cereals such as oatmeal (5.5 g water/g fiber) and wheat (6.6 g water/g fiber) ${ }^{[28]}$, the high water retention capacity of chia seed measured in this study $\left(24.0 \pm 0.879 \mathrm{~g} \cdot \mathrm{g}^{-1}\right)$ illustrates its high fiber content. Adams et al. [28] and Grigelmo-Miguel and Martín-Belloso [29] concluded that the higher soluble dietary fiber content increases the water retention capacity. Francki et al. [30] noted that soluble dietary fibers are easily fermentable by colonic bacteria, are characterized by high water retention and it have the capacity to form a gelatinous mass, which increases the viscosity of 
gastrointestinal contents and slows gastric emptying, providing greater lubrication and volume of stool.

Table 4. Lipid content and fatty acid composition of chia seed

\begin{tabular}{|c|c|}
\hline & g. $100 \mathrm{~g}^{-1}$ \\
\hline Lipids & 34,39 \\
\hline Saturated Fats & 9,74 \\
\hline Myristic acid (C14:0) & 0,03 \\
\hline Pentadecanoic acid (C15:0) & 0,03 \\
\hline Palmitic acid (C16:0) & 6,69 \\
\hline Margaric acid (C17:0) & 0,06 \\
\hline Stearic acid (C18:0) & 2,67 \\
\hline Behênico acid (C22:0) & 0,09 \\
\hline Tricosanoic (C23:0) & 0,03 \\
\hline Lignocérico acid (C24:0) & 0,14 \\
\hline Monounsaturated Fats & 10,76 \\
\hline Pentadecenóico acid (C15:1) & 0,03 \\
\hline Palmitoleic acid (C16:1) & 0,09 \\
\hline Oleic acid (C18:1 - $\omega-9)$ & 10,55 \\
\hline Cis-Eicosenóico acid (C20:1) & 0,09 \\
\hline Polyunsaturated Fats & 79,47 \\
\hline Linoleic acid (C18:2 - $\omega-6)$ & 17,36 \\
\hline Linolenic acid (C18:3 - $\omega-3)$ & 62,02 \\
\hline Cis-Eicosadienóico acid (C20:2) & 0,03 \\
\hline Cis-Eicosatrienóico acid (C20:3) & 0,03 \\
\hline Trans Fat & $\mathbf{0 , 0 3}$ \\
\hline Elaidic acid (C18:1) & 0,03 \\
\hline Unsaturated Fats & 90,26 \\
\hline
\end{tabular}

$\%$ of total lipids.

Comparing the results of chia seed oil in this study (Table 4) with Ayerza and Coates [11], we obtained similar values of palmitic acid (7\%), stearic acid (3.23\%), linolenic acid (60.68\%) and polyunsaturated fat (PUFA) (81.15\%), a lower value for linoleic acid (20.47\%) and a higher value for oleic acid (7.48\%). Similar to our results, Ixtaina et al. [3] classified the acids in the following order of abundance: linolenic acid (C18:3) >linoleic acid (C18:2) >oleic acid (C18:1) >palmitic acid (C16:0) >stearic acid (C18:0). However, some authors claim that the composition of oil, measured as percent fatty acids, is affected by the location of seed cultivation [11]. In addition, the proportion of $\omega-3 / \omega-6$ oil from chia in this study was 3.57, which is greater than most vegetable oils including canola oil (0.45), soybean oil (0.15) and olive oil (0.13) [31]. The incorporation of ingredients with high PUFA content into the diet provides numerous health benefits [32]. The chia seed can be considered a functional food because it is a source of $\omega$ 3 fatty acids, with at least $0.1 \mathrm{~g}$ of $\omega-3$ in $100 \mathrm{~g}$ of product [33], and has high levels of total dietary fiber, up to $3 \mathrm{~g}$ in $100 \mathrm{~g}$ of product [34] and protein.

Extraction, quantification and profiling of the phenolic compounds of chia seeds (Salvia hispanica $L_{\text {. }}$ ).
The coefficient of determination of the analytical curve of GAE was 0.983 , and the equation of the curve was $\mathrm{y}=$ $0,020 \times\left(\mu \mathrm{g} \cdot \mathrm{mL}^{-1}\right)$, where the concentration is on the $\mathrm{x}$ axis and absorbance on the y-axis. As shown in Table 5, the chia phenolic extracts were within the range found by Reyes-Caudillo et al. [10] (511-881 $\mu \mathrm{g}^{-\mathrm{g}^{-1}}$ chia seed).

Table 5. Content and profile of phenolic compounds $\left(\mu \mathrm{g}_{\mathrm{GAE}} \cdot \mathrm{g}_{\mathrm{amostra}}{ }^{-1}\right)$ of chia extracts

\begin{tabular}{ll}
\hline & $\mu^{\prime} \cdot$ gamostra $^{-1}$ \\
\hline Phenolic compounds & 641,71 \\
Cinnamic acid & ND \\
Chlorogenic acid & 4,68 \\
Caffeic acid & 30,89 \\
Quercetin & 0,17 \\
Phenolic Glycoside* & 605,97
\end{tabular}

ND (not detected); *phenolic glycoside: most likely a union glicídeo + phenolic compound.

The profile of phenolics showed a high content of caffeic acid compared with other phenols. Reyes-Caudillo et al. [10] studied the profile of phenolic compounds of chia seeds from two regions of Mexico, chlorogenic acid was predominant in crude phenolic compound extracts, ranging from 45.9-102 $\mu \mathrm{g}^{-\mathrm{g}^{-1}}$ chia, followed by caffeic acid

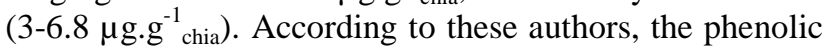
compound content is affected by a number of external factors, such as weather and post-harvest conditions. Kim et al. [35] suggested that two different methods of extraction can be used to obtain more information about the concentration of phenolics in chia seeds. Because the phenolic compounds may be in the form of polymers, esters and glycosides, enzymatic hydrolysis is used to quantify and verify the bioavailability of these compounds. These assays were used in the study of Reyes-Caudillo et al. [10], who found $651 \mu \mathrm{g}$.g chia $^{-1}$ of phenolic glycosides in crude phenolic compound extracts, similar to the values reported here.

\subsection{Antioxidant Activity of Phenolic Compounds from Chia (Salvia hispanica L.) Seeds}

Ability to sequestrate the DPPH free radical. The antioxidant activity of the phenolic extracts was determined by the inactivation of DPPH (Figure 1). The chia phenolic extract (32.35 $\mu \mathrm{g}_{\mathrm{GAE}} \cdot \mathrm{mL}_{\text {extract }}{ }^{-1}$ ) showed antioxidant activity that was statistically equal during the period from 120 to $210 \mathrm{~min}$. The extract was effective in neutralizing more than $70 \%$ of the free radicals. There was a significant difference between the chia extract and the control, a synthetic antioxidant (GAE). Based on these data, it is evident that bioactive components in the extracts act as radical sequestrators and hydrogen donors [36]. Comparing our results to the study by Schmidt et al. [37], the chia phenolic compounds showed high antioxidant activity in the DPPH assay. Phenolic compounds extracted from rice bran $\left(0.1 \mathrm{mg} \cdot \mathrm{mL}^{-1}\right)$ inhibit approximately $50 \%$ of the DPPH in the reaction after $30 \mathrm{~min}$. The bioactive, antioxidant components in these foods lower the incidence of cardiovascular disease and prevent the rancidity of unsaturated fatty acids [10]. 


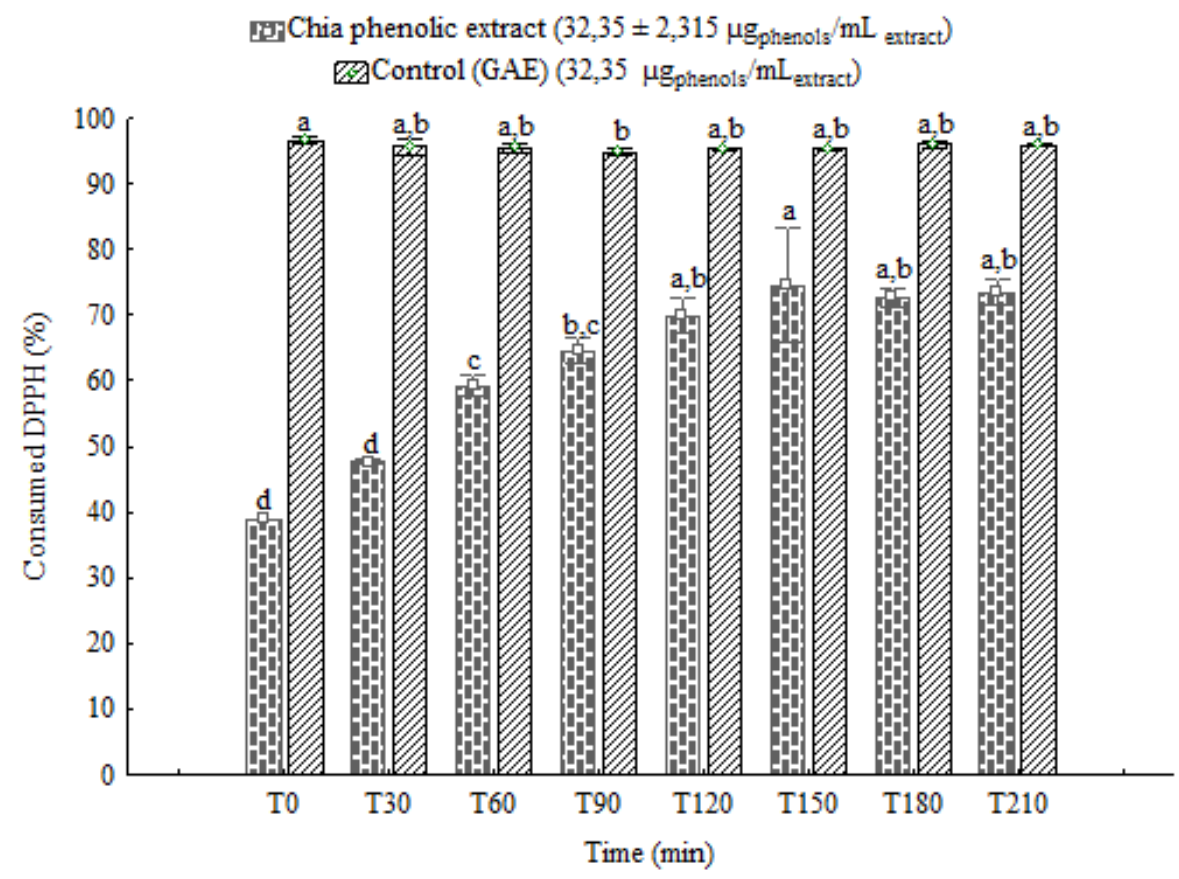

Figure 1. Percent DPPH inhibition by chia (Salvia hispanica, L.) extracts

Inhibition of enzymatically catalyzed oxidation. Chia phenolic extracts inhibited the oxidation of guaiacol
(Figure 2), and the rate of this inhibition was constant during the assay period.

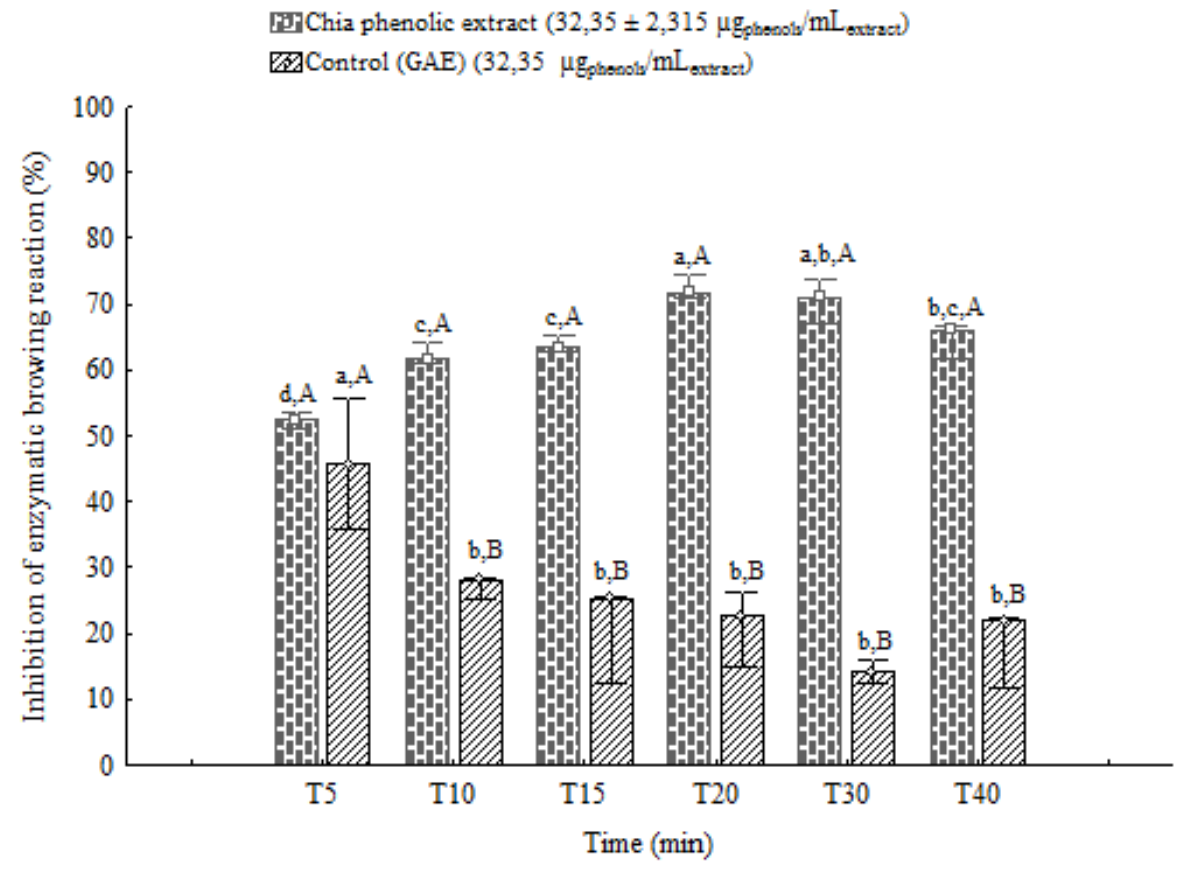

Figure 2. Percent enzymatic browning reaction inhibition by chia (Salvia hispanica L.) extracts

Compared with the control (GAE), there was no significant difference at 5 min of reactions, but at other times, the chia phenolic extract times showed higher antioxidant activity than the control. The chia seed antioxidant activity could have physiological effects, such as anticancer and antimutagenic activity, that remediate problems resulting from free radicals [38].

Compared with this study, Oliveira et al. ${ }^{[20]}$ found higher values in wheat and rice, with $50 \%$ and $60 \%$ inhibition of peroxidase in reactions containing 2.0 and $1.3 \mu g_{\text {phenols }} \cdot \mathrm{mL}^{-1}$ extracts, respectively, in $10 \mathrm{~min}$. Peroxidase is an important vegetable enzyme that is involved in various reactions, including polysaccharide synthesis, indole-3-acetic acid oxidation, formation of linkages between monomers, lignification, phenol oxidation, pathogen defense, and regulation of cell elongation [39].

\section{Conclusions}

In conclusion, chia seeds showed high levels of lipids, proteins and fibers compared with other seeds. It is suggested that fiber, one of the components of chia, due to 
its high water retention capacity, are important for the production of other products such as emulsifiers. In addition, chia seeds presented high content of phenolic compounds with antioxidant activity effectively suggesting that chia can bring health benefits when used in food products. The diversity along with the amount of nutrient composition in chia seed can help to have a healthy diet and add value in the preparation of products.

\section{Funding}

We thank the Coordenação de Aperfeiçoamento de Pessoal de Nível Superior (CAPES) for supporting this study and companies Chá e Cia - Ervas Medicinais for supplying the raw materials.

\section{Abbreviations Used}

GAE, gallic acid.

\section{References}

[1] Ali, N.M., Yeap, S.K., Ho, W.Y., Beh, B.K., Tan, S.W. and Tan, S.G., "The promising future of chia, Salvia hispanica L.", J Biomed Biotechnol, 2012, 1-9, 2012.

[2] Coates, W. and Ayerza, R., "Production potential of chia in northwestern Argentina”, Ind. Crop Prod., 5, 229-23, 1996.

[3] Ixtaina, V.Y., Martínez, M.L., Spotorno, V., Mateo, C.M., Maestri, D.M. and Diehl, B.W.K., "Characterization of chia seed oils obtained by pressing and solvent extraction", J Food Comp Anal, 24(2), 166-174, 2011.

[4] Mcclements, D.J., Decker, E.A. and Weiss, J., "Emulsion-based delivery systems for lipophilic bioactive components", J Food Sci, 72, R109-R124, 2007.

[5] Pacheco, M.T.B. and Sgarbieri, V.C., Alimentos funcionais: conceituação e importância na saúde humana. Instituto de Tecnologia de Alimentos ITAL, Campinas, 2001, 13073-14001.

[6] Al-Sheraji, S.H., Ismail, A., Manap, M.Y., Mustafa, S., Yusof, R.M. and Hassan, F.A., "Prebiotics as functional foods: A review", J Funct Foods, 5(4), 1542-1553, 2013.

[7] Alu'datt, M.H., Rababah, T., Ereifej, K. and Alli, I., "Distribution, antioxidant and characterisation of phenolic compounds in soybeans, flaxseed and olives", Food Chem, 139(1-4), 93-99, 2013.

[8] Amarowicz, R., Naczk, M. and Shahidi, F., "Antioxidant activity of various fractions of non-tannin phenolics of canola hulls", $J$ Agric Food Chem, 48, 2755-2759, 2000.

[9] Mason, M.J., Scammon, D.L. and Fang, X., "The impact of warnings, disclaimers, and product experience on consumers' perceptions of dietary supplements”, J Consum Affairs, 41, 74-99, 2007.

[10] Reyes-Caudillo, E., Tecante, A. and Valdivia-López, M.A., "Dietary fibre content and antioxidant activity of phenolic compounds present in Mexican chia (Salvia hispanica L.) seeds", Food Chem, 107, 656-663, 2008.

[11] Ayerza, R. and Coates, W., Chia seeds: New source of omega-3 fatty acids, natural antioxidants, and dietetic fiber. Tucson, Arizona, USA: Southwest Center for Natural Products Research \& Commercialization, Office of Arid Lands Studies, 2001, 3.

[12] Craig, R. Application for approval of whole chia (Salvia hispanica L.) seed and ground whole seed as novel food ingredient. Food Standard Agency, UK. Commission Decision 2009/827/EC Company Representative Mr. D. Amstrong, Northern Ireland, 2004.

[13] AOAC - Association of Official Analytical Chemists. Official Methods of Analysis of International. 17 th. 1 CD-ROM, 2000.

[14] Watt, B. and Merrill, A.L., Composition of foods: raw, processed, prepared. Washington, DC: Consumer and Food Economics Research Division / Agricultural Research Service, 198 (Agriculture Handbook, 8), 1963.
[15] Regenstein, J.M., Gorimar, T.S. and Sherbon, J.M., "Measuring the water capacity of natural actomyosin from chicken breast muscle in the presence of pyrophosphate and divalent cation”, $J$ Food Biochem, 3, 205-211, 1979.

[16] AOAC - Association of Official Analytical Chemists. Official Methods of Analyses of the Association of Analytical Chemists. 18 ed. CD-ROM, 2005.

[17] Badiale-Furlong, E., Colla, E., Bortolato, D.S., Baisch, A.L.M. and De Souza-Soares, L.A., "Avaliação do potencial de compostos fenólicos em tecidos vegetais”, Vetor, 13, 105-114, 2003.

[18] Macedo, J.A., Battestin, V., Ribeiro, M.L. and Macedo, G.A., "Increasing the antioxidant power of tea extracts by biotransformation of polyphenols", Food Chem, 126, 491-497, 2011.

[19] Herrero, M., Martín-Álvarez, P., Señoráns, F.J., Cifuentes, A. and Ibáñez, E., "Optimization of accelerated solvent extraction of antioxidants from Spirulina platensis microalgae”, Food Chem, 93, 417-423, 2005.

[20] Oliveira, M.S., Dors, G.C., Souza-Soares, L.A. and BadialeFurlong, E., "Atividade antioxidante e antifúngica de extratos vegetais”, Rev Alim Nutr, 18(3), 267-275, 2007.

[21] Tosco, G., Os benefícios da "chia" em humanos e animais. Atualidades Ornitológicas, 2004, 119.

[22] Segura-Campos, M.R., Salazar-Veja, I.M., Chel-Guerrero, L.A. and Betancur-Ancona, D.A., "Biological potential of chia (Salvia hispanica L.) protein hydrolysates and their incorporation into functional foods", Food Sci Technol, 50, 723-731, 2013.

[23] Lima, D.M., Padovani, R.M., Rodriguez-Amaya, D.B., Farfán, J.A., Nonato, C.T. and De Lima, M.T., Tabela brasileira de composição de alimentos. NEPA/UNICAMP.- 4. ed., Campinas: NEPA - UNICAMP, 2011, 161.

[24] Novello, D. and Pollonio, M.A.R. "Adição de linhaça dourada (Linum usitatissimum L.) e derivados em hambúrgueres bovinos: aceitação sensorial e análise de sobrevivência”, B. Ceppa, 30, 2, 273-286, 2012.

[25] Castro, A.G. de., "A química e a reologia no processamento dos alimentos”, Ciência técnica, 25, 295, 2003.

[26] Jin, F., Nieman, D.C., Sha, W., Xie, G., Qiu, Y. and Jia, W. "Supplementation of milled chia seeds increases plasma ALA and EPA in postmenopausal women”, Plant Foods Hum Nutr, 67, 105110, 2012.

[27] Muñoz, L.A., Cobos, A., Diaz, O. and Aguilera, J.M., "Chia seeds: Microstructure, mucilage extraction and hydration", J Food Eng, 108, 216-224, 2012.

[28] Adams, R.G., Evans, A.J., Oakenfull, D.G. and Sidhu, G.S., "Fruit processing wastes as dietary fibre supplements", Proc Nutr Soc Aust, 11, 115, 1986.

[29] Grigelmo-Miguel, N. and Martin-Belloso, O. "Characterization of dietary fiber from orange juice extraction”, Food Res Int, 31, 355361, 1998.

[30] Francki, V.M., Gollucke, A.P.B. and Pimentel, C.V.B. Introdução às principais substâncias bioativas. Editora Varella, São Paulo, 2005.

[31] Belitz, H.D. and Grosch, W. Food Chemistry, 2nd ed. SpringerVerlag, Berlin, Germany, 1999.

[32] Bowen, R.A.R. and Clandinin, M.T., "Maternal dietary 22:6n-3 is more effective than 18:3n-3 in increasing content in phospholipids of glial cells from neonatal rat brain”, Brit J Nutr, 93, 601-611, 2005.

[33] Brazil, Ministério da Saúde, ANVISA. Alimentos com Alegações de Propriedades Funcionais e ou de Saúde, Novos Alimentos/Ingredientes, Substâncias Bioativas e Probióticos, 2008 Diário Oficial da União, Brasília, DF. Disponível em: $<$ http://www.anvisa.gov.br/alimentos/comissoes/tecno_lista_alega. htm>. Acesso: 23 jan/2104.

[34] Brazil, Ministério da Saúde, ANVISA. Resolução nº 27, de 13 de janeiro de 1998. Aprova o Regulamento Técnico referente à Informação Nutricional Complementar (declarações relacionadas ao conteúdo de nutrientes), 1998. Diário Oficial da União, Brasília, DF.

[35] Kim, K.H., Tsao, R., Yang, R. and Cui, S.W., "Phenolic acid profiles and antioxidant activities of wheat bran extracts and the effect of hydrolysis conditions”. Food Chem, 95, 466-473, 2006.

[36] Shahidi, F., "Nutraceuticals and functional foods: whole versus processed foods", Trends Food Sci. Technol., 20, 376-387, 2009.

[37] Schmidt, C.G., Gonçalves, L.M., Prietto, L., Hackbart, H.S. and Furlong, E.B., "Antioxidant activity and enzyme inhibition of 
phenolic acids from fermented rice bran with fungus Rizhopus oryzae", Food Chem, 146, 371-377, 2014.

[38] Moraes, F.P. and Colla, L.M., "Functional foods and nutraceuticals: definition, legislation and health benefits", Braz $J$ Pharm, 3, 2, 99-112, 2006.
[39] Kao, C.H., "Differential effect of sorbitol and polyethylene glycol on antioxidant enzymes in rice leaves", Plant Growth Regul., 39, 83-89, 2003. 